UDC $007: 303.442 .22(070)$

\title{
The Essence of the Fact Phenomenon and its Functioning in Media
}

\author{
Maria Komova * \\ Lviv Polytechnic National University, Department of Social Communication and Information \\ Activities, 12 St. Bandera Street, Lviv, 79013, Ukraine \\ * Corresponding author's e-mail address: maria.komova@gmail.com
}

\begin{abstract}
Application of the factual principle of information presentation is particularly relevant in present conditions of global usage of information space as a confrontation field for different models of development. Main objective of the study is to analyze the basic substantiating status of fact and its interpretation in the media system. Methodology of research is based on systematization and classification. The method of systematization is applied to integrate the nature of the fact phenomenon and its representation in the media system, and to determine the functional characteristics of the factual principle of information presentation in mass media. The method of classification is applied to establish a classification system qualifying different classes of facts.

Results / findings. Factual principle is implemented within the factual field, which is a set of information about changes in social environment integrated with lexical, grammatical, logical and stylistic ties, with appropriate focus and pragmatic attitude. The factual field is shaped by the interrelated system consisting of basic fact, factual environment and journalistic skills to convince by arguments based on facts. Factual principle of providing information to the media is based on the following functional characteristics: universality, consistency, analyticity, reliability, professionalism of fact presentation. The aim of facts classifications is to differentiate the objects reflected in the media by certain defining characteristics. Classification schemes are created on the basic of various logical processes: species classification is based on differentiation, while typological classification is based on integration features.

Conclusions. The essence of the fact phenomenon and its representation in the media is implemented by the universal application of the factual principle of information presentation. The factual field is an organic component of social interaction, and its consistency is shaped by the interrelation of objective and subjective factors. The classification and typology of facts provide a basis for establishing the specificity of each species and types of facts and of factual information created on their basis. It also helps to navigate in the information environment, to use effectively the factual data to rationalize messages in mass media. Significance of the study: the theory of fact is substantiated, its functional characteristics are determined, and the model of fact classification is developed.
\end{abstract}

KEYWORDS: fact, factual information, mass media, classification. 


\section{Сутність феномену факту та його функціонування в мас медіа}

Комова Марія Василівна, Національний університет «Львівська політехніка», кафедра соціальних комунікацій та інформаційної діяльності, доцент, кандидат філологічних наук

\section{Резюме}

Застосування фактологічного принципу представлення інформації набуває актуальності в умовах глобального використання інформаційного простору як поля протистояння різних моделей цивілізаційного розвитку. Мета дослідження полягає в обгрунтуванні базового статусу факту та його інтерпретацій в системі мас медіа. Методологія проведення аналізу грунтується на використанні методів систематизації та класифікації. Результати: досліджено сутність феномену факту та його функціонування в мас медіа; визначено функціональні характеристики фактологічного принципу подання інформації в мас медіа. Запропоновано систему класифікації фактів. Висновки: сутність феномену факту та його представлення в мас медіа виявляється в застосуванні фактологічного принципу подання інформації в ЗМІ. Системність фактологічного поля виявляється у взаємозв'язку об’єктивних і суб'єктивних чинників. Класифікація фактів допомагає орієнтуватися у інформаційному середовищі, ефективно використовувати факти для аргументації і доказовості повідомлення в мас медіа.

Ключові слова: факт, фактологічна інформація, мас-медіа, класифікація.

Комова М.В. Сущность феномена факта и его функционирования в масс медиа Резюме. Применение фактологического принципа представления информации приобретает актуальность в условиях глобального использования информационного пространства как поля противостояния различных моделей цивилизационного развития. Цель исследования заключается в обосновании базового статуса факта и его интерпретаций в системе масс медиа. Методология проведения анализа основывается на использовании методов систематизации и классификации. Результаты: исследована сущность феномена факта и его функционирования в масс медиа; определены функциональные характеристики фактологического принципа представления информации в масс медиа. Предложена система классификации фактов. Выводы: сущность феномена факта и его представление в масс медиа реализуется в применении фактологического принципа представления информации в СМИ. Системность фактологического поля проявляется во взаимосвязи объективных и субъективных факторов. Классификация фактов помогает ориентироваться в информационной среде, эффективно использовать факты для аргументации и доказательности сообщения в масс медиа.

Ключевые слова: факт, фактологическая информация, СМИ, классификация. 


\section{1. Вступ}

Факти становлять очевидну зміну об'єктивної реальності, результат соціальної комунікації та пізнавальної діяльності людини. Під час комунікаційної взаємодії, що реалізується за допомогою мас медіа, факт виконує свою головну системну функцію - бути підтвердженням (спростуванням) еволюції в елементарній, біологічній, соціальній комунікації, що зумовлено універсальним характером об'єктів представлення в мас-медійній практиці. Застосування фактологічного принципу представлення інформації набуває особливої актуальності в сучасних умовах глобального використання інформаційного простору як поля протистояння різних моделей цивілізаційного розвитку.

Мета дослідження полягає в обгрунтуванні базового статусу факту та його інтерпретацій в системі мас медіа. Для реалізації цієї мети необхідно вирішити завдання: з'ясувати сутність феномену факту та його функціонування в мас медіа; вивчити суттєві зв'язки між різними за своєю природою фактами, що представляються в мас медіа; визначити функціональні характеристики фактологічного принципу подання інформації в мас медіа; розробити класифікаційну систему фактів відповідно до визначених ознак.

Питання функціонування фактологічної інформації у журналістській діяльності, використання фактологічного принципу представлення інформації в мас медіа розглядали в різних аспектах українські та зарубіжні теоретики журналістики і масової комунікації (М. Василенко, В. Демченко, В. Качкан, В. Лизанчук, Б. Потятиник, В. Різун, А. Чічановський, В. Шкляр, 3. Вайшенберг, Ж. Бодрійяр).

У руслі доктрини об’єктивності новин В. Різун наголошує на суб'єктивному характері фактологічної інформації, трактуючи факт як принцип членування соціальної дійсності людьми, як продукт діяльності людини 3 дійсністю, про яку людина формує знання. Учений визначив факт як суб'єктивну даність, оскільки він є частинкою пізнаного людиною предметного світу, а сфера людського відображення, відчуття - суб'єктивні [1]. В. Різун наголошує на обов'язковій наявності оцінного компоненту у поданні фактологічної інформації в ЗМI: «Оцінне судження, яке базується на порівняно достовірних фактах, - це публіцистична класика і якість!» [2].

Досліджуючи філософсько-методологічні засади сучасної теорії публіцистики, український науковець О. Александров актуалізує питання щодо функціонування фактологічної інформації в публіцистичному творі і його спроможності впливати на споживача інформації. Цінними є погляди вченого на застосування принципу концептуальності представлення фактологічного матеріалу. Визначаючи філософські аспекти співвідношення факту і авторської концепції, О. Александров підкреслює індивідуальність, конкретність, одиничність зв'язків факту та узагальненість концепції, завдяки якій факт пізнається та оцінюється не 3 позиції сьогодення, а як чинник майбутнього. Без концепції дійсності, без авторського бачення того чи іншого факту чи стану цілого світу така інтелектуальна операція неможлива, а публіцистичний твір буде позбавлений впливовості на читача. Аналізуючи специфіку структури публіцистичного твору, форми викладу, вчений підкреслює бінарність його структури, зумовлену часовими і просторовими характеристиками події, що зумовлює синтетичність, інтегративність риторичних і наративних засад представлення фактичного матеріалу в публіцистичному творі [3].

Зігфрид Вайшенберг, очільник Інституту журналістики та комунікації Гамбурзького університету, у фактологічній базі новинного повідомлення вбачає серцевину, яка шляхом iii інтерпретації може набувати найрізноманітніших ракурсів чи тлумачень. У новинному масово-комунікаційному продукті факт завжди виявляє такі властивості, як універсальність та обов'язковість, що зумовлено специфікою новинної журналістики. На думку 3.Вайшенберга, факт існує в ключових поняттях новинної журналістики: призначення задоволення суспільних потреб у знанні про зміни в світі; предмет відображення - реальне 
суспільно важливе явище в час його очевидної зміни; функція - інформувати громадськість про зміни в реальному суспільно важливому явищі [4].

В умовах глобального протистояння моделей цивілізаційного розвитку винятково важливого значення набувають теорії інтерпретації фактів та використання фактологічної інформації за допомогою мас медіа для досягнення певних практичних цілей. Ж. Бодрійяр, французький філософ, публіцист, створивши оригінальну теорію симулякрів, обгрунтував технології трансформації реальності в гіперреальність. На думку вченого, симуляція підмінює реальне знаками реального, тобто відбувається апотропія будь-якого реального процесу з допомогою його операційної копії, запрограмованого механізму, який має всі знаки реального. Таким чином, технологія деформованого представлення реальних фактів трансформує об’єктивну реальність, що дозволяє мас медіа здійснювати глобальне маніпулювання суспільною свідомістю [5].

\section{2. Методи дослідження}

Методологія проведення аналізу грунтується на використанні таких методів наукового пізнання, як методи систематизації та класифікації.

Метод систематизації використовується для зведення та інтеграції розрізних знань про сутність феномену факту та його функціонування в системі мас медіа; для вивчення суттєвих зв'язків між різними за своєю природою фактів, що оприлюднюється в мас медіа; для визначення функціональних характеристик фактологічного принципу подання інформації в мас медіа; для висунення фундаментальної ідеї щодо закономірностей та особливостей функціонування фактологічної інформації в мас медіа.

Метод класифікації використовується для створення системи розподілу фактів за класами відповідно до визначених ознак, враховуючи їхні особливості.

\section{3. Результати і обговорення}

Фактологічний принцип подання інформації в ЗМІ виявляється в межах фактологічного поля, яке являє собою комплекс відомостей про зміни в соціальному середовищі, подання яких інтегровано лексичними, граматичними, логічними, стилістичними зв'язками, має відповідну спрямованість і прагматичну настанову. Фактологічне поле охоплює базовий факт, фактологічне середовище, а також засоби журналістської майстерності переконувати аргументами, що грунтуються на фактах.

Базовий факт як реальна подія, апріорі відповідаючи ключовим вимогам (викликати суспільний інтерес; мати інформаційну цінність, тобто бути новиною; бути достовірним, оперативним і повним), становить комунікаційне ядро, стрижень повідомлення в масовокомунікативному процесі. Потрапляючи в сферу уваги і відображення 3МI, факт зазнає певних перетворень перш, ніж він буде представлений в тій чи іншій формі. Як зазначав Ю. Лотман, перетворення події в текст означає переказ його в системі тієї або іншої мови, тобто підпорядкування заздалегідь певній структурній організації. Текст як інформаційний зміст документа, програми, повідомлення, виконує низку функцій, які реалізують як інформаційне, так і комунікаційне призначення тексту, а саме: повідомлення, скероване від носія інформації до суб'єкта; колективна пам'ять, здатна до безперервного поповнення, актуалізації одних аспектів інформації і до тимчасового або повного забуття інших; текст стає співбесідником; спілкування між текстом і культурним контекстом [6].

Фактологічне середовище повідомлення формують такі факти, які ілюструють базовий факт. Фактологічне середовище належить як невід'ємний компонент до соціальнокомунікаційного середовища, тобто сукупності комунікаційних умов суспільства, які 
створюються внаслідок формування численних перетворених форм смислотворчої діяльності, результати якої призначені безпосередньо для системи соціальної взаємодії або опосередковано для інших сфер соціальної практики, які генералізують потоки інформації і знань для подальшого опрацювання в структурах соціальної комунікації.

Фактологічному середовищу належить ключова роль в реалізації основних характеристик тексту, до яких, на думку М.Яцемірської, належать логічна завершеність висловлень, комунікаційні наміри, прагматична настанова [7]. Один і той самий базовий факт на різному фактологічному тлі може мати різне забарвлення, а відповідно здійснювати різну соціальну взаємодію, тобто безперервний обмін соціальною інформацією в комунікаційному процесі.

Успішне застосування фактологічного принципу подання інформації в засобах масових комунікацій залежить від журналістської майстерності переконувати фактами, відбирати їх $з$ поточної дійсності, узагальнювати, аналізувати, встановлювати їхній зв'язок i взаємозалежність, вибудовувати на свої міркування та ідеї. За медіатекстом стоять мовні особливості журналіста, його світогляд, інтелектуальний та професійний рівень, когнітивні здібності [7].

Журналістська майстерність виявляється у дотриманні вимог логічної і лінгвістичної системності при висвітленні фактів. Логічна системність передбачає дотримання точності і вірогідності висвітлення фактологічної бази (посилання, свідчення, цитати; визначення місця, часу, обставин); ясності викладу (уточнення, зіставлення цитат, розповідей очевидців про їхній власний досвід); ясності ситуації, зображеної журналістом; визначеності ставлення журналіста до певного факту; наочності (врахування фактологічних деталей, сильних своєю очевидністю). Лінгвістична системність передбачає дотримання передусім стилістичних особливостей журналістських творів в ЗМІ: стислість, вивірена довжина i ритміка повідомлення, точність і простота слів і фраз.

Фактологічний принцип подання інформації в ЗМІ грунтується на таких функціональних характеристиках, як універсальність поширення, системність подання фактів, асоціативність подання фактів, аналітичність подання фактів, достовірність подання фактів. професійність подання фактів.

Універсальність поширення фактологічного принципу відображення дійсності полягає в його реалізації в усіх жанрах журналістської творчості. Загальною для всіх жанрів якістю є здатність виділяти з потоку подій найбільш визначні, яскраві факти, підкреслювати подію, факт як осередок інтересу.

Системність подання фактів у процесі журналістської творчості виявляється у фіксації одиничного факту, в узагальненні його характеристик у контексті суми фактів, узятих у їхньому розвитку, у формуванні системи фактів та осмисленні та розкритті сутності явища як інтегрованих систем фактів. Цей ланцюг логічних операцій дає можливість комплексно i системно реалізувати фактологічний принцип представлення інформації в ЗМІ: одиничний факт - сума фактів - система фактів - явище. Представити одиничний факт як виявлення явища - одна 3 найважливіших професійних якостей журналіста. Факт вступає у зв'язок з іншими фактами та із загальними положеннями.

Асоціативність подання фактів виявляється у функціональній парадигмі факту, що виявляється в його існуванні в асоціативних зв'язках. У публіцистиці факти часто поєднуються на основі асоціативних зв'язків, коли поєднуються факти, які не причетні до однієї події, не пов'язані між собою ні в часі, ні в просторі. Асоціативні зв'язки грунтуються на моральних, морально-етичних аспектах двох фактів, які не перебувають у фактологічному полі певної події, явища. Факти пов’язуються в єдину моральну сутність.

Аналітичність подання фактів реалізується у творах коментувальної публіцистики, в яких факти коментуються, вивчаються, аналізуються. Тут факти служать для журналіста підмогою, відправною точкою журналістського виступу. Мистецтво публіцистичного 
аналізу, уміння стежити, досліджувати факти і на основі їх робити висновки, узагальнення - основна частина в роботі журналіста при підготовці і написанні коментаря, статті, огляду.

Достовірність подання фактів грунтується на задоволенні комунікаційних потреб читачів у публіцистичних творах, у новинній інформації, будь-якого журналістського тексту як документа, що апріорі володіє ознакою істинності та обгрунтованості. На жаль, сьогодні ця настанова не завжди знаходить підтвердження: у реальній практиці журналісти занадто часто використовують неперевірені факти, а іноді і спеціально «винайдені» заради сенсаційної чутки, порушуючи фактологічний принцип представлення реалій соціального життя. За медіатекстом, що містить фактоїди, можуть стояти міркування і мотиви, не пов'язані з журналістською творчістю, що грунтується на фактологічних та документальних принципах об'єктивності та достовірності. Фактоїди представлені в регіональних, національних і міжнародних медіатекстах з широким тематичним спектром. Вони є винятково дієвим засобом маніпулювання масовою свідомістю [8].

Професійність подання фактів виявляється в тому, що еволюційна зміна критеріїв якості роботи журналістів зумовила поступове витіснення вислову «новина для преси» на вислів «новина преси», визначаючи факт не як «сировину», а як матеріал, опрацьований в особливому літературному продукті. Професійне відчуття репортерами придатності факту для «подання» як новини, передбачає їхню здатність на когнітивному та інтуїтивному рівні розрізняти такі прикмети факту, які обіцяють цікавий для аудиторії матеріал.

На особливості застосування фактологічного принципу представлення інформації в засобах масових інформації впливають: конкуренція серед видань і агентств; наявність новин про певні факти на інших каналах інформації; визначена редакційна політика видання; змушене або навмисне комбінування новин факти місцевого, загальнодержавного і міжнародного значення, важливих і цікавих фактів суспільного життя; розмір площі, яка відводиться.

Інтерпретаційна компонента у фактологічній інформації вступає в суперечність із принципом об'єктивності новин. Наявність оцінки, що виявляє суб'єктивне ставлення до об'єктивної дійсності, є обов'язковим елементом новинного повідомлення, яке може мати за мету (а особливо в умовах ведення інформаційної війни) маніпуляцію суспільною свідомість, зомбування. Саме тому, на думку В. Різуна, учасникам комунікаційної взаємодії слід ставитися до інформації, що містить фактичний матеріал, як до речі сумнівної і неточної, яка вимагає перевірки, наукового аналізу [2].

Вагомою компонентою методології дослідження феномену факту є розроблення класифікації та типологізації фактів. Класифікація фактів, як і видове групування будь-яких інших сутностей, грунтується на таких логічних засадах, як єдність ознак, співрозмірність членів ділення, їхнє взаємовиключення, непервність ділення. Єдність ознак поняття факт передбачає диференціацію фактів за однією із найсуттєвіших ознак. В основу видової класифікації фактів покладено три блоки ознак відповідно до різних характеристик фактів: атрибутивність, функціональність, якість.

Атрибутивні види фактів визначаються їхніми сутнісними соціальними характеристиками, без яких факт не може існувати: наявність явища в певних просторово-часових координатах (Табл. 1). Розглядаючи сутність речей як філософську категорію, що позначає внутрішні, найбільш глибокі, сталі властивості і відношення предмета, визначає походження, внутрішні зв'язки й тенденції розвитку і пізнається на рівні теоретичного мислення, акцентуємо увагу на механізмах процесу пізнання, внаслідок якого сутність розкриває себе у зовнішніх явищах суспільної дійсності. Явище, відображаючи зовнішні властивості, процеси, зв'язки предмета, які пізнаються безпосередньо в формах живого споглядання, входить в соціальне буття шляхом презентації в ЗМІ, пройшовши стадії діалектики пізнання: об’єктивне існування явища в соціальній дійсності $\rightarrow$ повідомлення про явище в 
ЗМІ $\rightarrow$ зворотна реакція аудиторії на повідомлення про явище. Так явища набувають статусу оприлюднених фактів, що мають різний ступінь соціальної вагомості і резонансності в певних просторово-часових координатах. Саме на цих стадіях породжуються види фактів, які можна вважати атрибутивними: вони вказують на категорію факту - об’єкту відображення та факти, що свідчить про просторово-часові координати, сферу поширення.

Функціональні види фактів визначаються виконанням певних функцій у структурі елементарних виражальних засобів у тексті (Табл. 2).

Якісні види фактів визначаються за їхніми властивостями, які виявляються під час відображення реальності. Факт, головною ознакою якого є зміна реальної конкретної ситуації, у соціальній комунікації виявляє такі властивості, як адекватність (співвіднесеність 3 реальністю), актуальність (соціальна важливість), обгрунтованість (підтвердженість документом), динамічність (невичерпність), експресивність (сенсаційність) (Табл. 3).

Типологізація фактів пов'язана з групуванням фактів на основі їх відповідності певній узагальненій моделі - типу, тобто найсуттєвішим рисам, властивим певній групі фактів. Типологія факту визначає його належність до певного типу за сукупністю ознак. Визначаючи основною типоутворювальною ознакою фактів належність до певної сфери суспільного життя, виділяємо такі типи фактів: офіційний, науковий, громадсько-політичний, виробничий, культурологічний, побутовий (Табл. 4).

Таблиця 1. Атрибутивні види фактів

\begin{tabular}{|l|l|}
\hline Ознака класифікації & Вид фактів \\
\hline \multirow{2}{*}{$\begin{array}{l}\text { категорія факту - об’єкту } \\
\text { відображення }\end{array}$} & факт-дія, процес (подія, пригода, захід, акція) \\
\cline { 2 - 2 } $\begin{array}{l}\text { просторово-часові коорди- } \\
\text { нати, сфера поширення }\end{array}$ & макт-рішення (план, програма, інформаційний лист) \\
\cline { 2 - 2 } & регіональний факт \\
\cline { 2 - 2 } & загальнодержавний факт \\
\cline { 2 - 2 } & міжнародний факт \\
\hline
\end{tabular}

Таблиця 2. Функціональні види фактів

\begin{tabular}{|c|c|}
\hline Ознака класифікації & Вид фактів \\
\hline \multirow{8}{*}{$\begin{array}{l}\text { призначення факту у } \\
\text { структурі елементарних } \\
\text { виражальних засобів у } \\
\text { тексті }\end{array}$} & факт-привід \\
\hline & факт-причина \\
\hline & $\begin{array}{l}\text { факт-наслідок, зворотна реакція аудиторії (зведення, звіт, } \\
\text { доповідь, презентація, прес-реліз, довідка, коментар } \\
\text { експерта) }\end{array}$ \\
\hline & факт-деталь \\
\hline & факт-акцент (поворотні моменти) \\
\hline & факт-свідчення \\
\hline & ключовий факт, що змінює ситуацію \\
\hline & $\begin{array}{l}\text { фактологічне середовище (група фактів, що змінюють } \\
\text { ситуацію) }\end{array}$ \\
\hline
\end{tabular}


Таблиця 3. Якісні види фактів

\begin{tabular}{|l|l|}
\hline Ознака класифікації & Вид фактів \\
\hline \multirow{5}{*}{ адекватність } & власне факт, що відтворює реалії об’єктивного світу \\
\cline { 2 - 2 } & $\begin{array}{l}\text { фактоід - позначення реалій, що неповно піддаються } \\
\text { перевірці }\end{array}$ \\
\cline { 2 - 2 } & факт-емпіризм - узагальнення реалій на досвіді, «на око» \\
\hline \multirow{2}{*}{ обгрунтованість } & факт, що грунтується на документі \\
\cline { 2 - 2 } & факт, що існує в масовій свідомості \\
\hline \multirow{2}{*}{ динамічність } & факт-подія (ситуація) в розвитку \\
\cline { 2 - 2 } & факт позитивної (негативної) зміни ситуації \\
\hline \multirow{2}{*}{ експресивність } & «жорсткий» факт \\
\cline { 2 - 2 } & «м’який» факт \\
\hline
\end{tabular}

Таблиця 4. Типологія фактів

\begin{tabular}{|l|l|}
\hline Сфера суспільного життя & Тип факту \\
\hline управління суспільством & офіційний факт \\
\hline освіта і наука & науковий факт \\
\hline громадсько-політичне життя & громадсько-політичний факт \\
\hline техніка і виробництво & виробничий факт \\
\hline література, культура, мистецтво, спорт & культурологічний факт \\
\hline побутове життя & побутовий факт \\
\hline
\end{tabular}

\section{4. Висновки}

Сутність феномену факту та його представлення в мас медіа виявляється в універсальності застосування фактологічного принципу подання інформації в ЗМІ. Фактологічний принцип реалізується в межах фактологічного поля, яке являє собою комплекс відомостей про зміни в соціальному середовищі, подання яких інтегровано лексичними, граматичними, логічними, стилістичними зв'язками, має відповідну спрямованість і прагматичну настанову. Фактологічне поле формує система взаємопов'язаних чинників: базовий факт, який становить комунікаційне ядро, стрижень повідомлення в масово-комунікативному процесі; фактологічне середовище, яке формують такі факти, які ілюструють базовий факт; журналістська майстерність, яка охоплює вміння переконувати доказами та аргументами, що грунтуються на фактах. Фактологічне поле виступає органічним компонентом соціальної взаємодії. Системність і комплексність фактологічного поля виявляється у взаємозв'язку об'єктивних (базовий факт, фактологічне середовище), і суб'єктивних (засоби журналістської майстерності) чинників.

Фактологічний принцип подання інформації в 3МІ грунтується на таких функціональних характеристиках, як універсальність, системність, асоціативність, аналітичність, достовірність, професійність подання фактів. 
Сутність видової і типологічної класифікації фактів полягає у диференціації об'єктів відображення в мас медіа за певними визначальними ознаками. Видова і типологічна класифікаційні схеми створюється на основі різних логічних процесів: в основу видової класифікації покладено диференціацію ознак, в основу типологізації - їх інтеграція. Класифікація і типологізація фактів створює основу для встановлення специфіки кожного виду і типу фактів та створюваної на їхній основі фактологічної інформації, допомагає орієнтуватися у інформаційному середовищі, ефективно використовувати фактичний матеріал для аргументації і доказовості повідомлення в мас медіа.

\section{References}

1. Rizun, V. (2004), "Problems and prospects prospects for the development of journalism education in Ukraine in the early XXI century", Naukovi Zapysky Instytutu Zhurnalistyky, vol. 16, pp. 6-13.

2. Rizun, V. (2010), "Problems and prospects of development of journalism education in an unstable society", in Global standards of journalism, Cherkasy, pp. 59-67.

3. Aleksandrov, O. (2007), "Proceedings of the theory of journalism", Dialoh. MediaStudiyi, no 6, pp. 282-288.

4. Vayshenberh, Z. (2004), News Journalism, Akademiya Ukrayins'koyi presy, Kyiv, 262 p.

5. Bodriyyar, Zh. (2004), Simulacra and simulation, Vyd-vo Solomiyi Pavlychko "Osnovy", Kyiv, 230 p. $703 \mathrm{p}$.

6. Lotman, Yu. (2004), Semyosfera: Culture and Explosion, Yskusstvo, Saint Petersburg,

7. Yatsemirska, M. (2004), Culture Professional Language of Journalist, PAIS, L'viv, 368 p.

8. Shchukyna, L. (2003), "Problem factors in modern television advertising", in Problemy Massovoy Kommunykatsyy na Rubezhe Tysyacheletyy, Voronezh, p.146.

\section{Список джерел}

1. Різун В. В. Проблеми й перспективи розвитку журналістської освіти в Україні на початку XXI століття / В. В. Різун // Наукові записки Інституту журналістики. - 2004. - Т. 16. - C. 6-13.

2. Різун В. В. Проблеми й перспективи розвитку журналістської освіти в умовах нестабільного суспільства / В. В. Різун // Світові стандарти журналістики: зб. наук. праць. - Черкаси, 2010. - С. 59-67.

3. Александров О. В. Тези до теорії публіцистики / О. В. Александров // Діалог. Медіа-студії: зб. наук. праць / Одес. нац. ун-т ім. I.I. Мечнікова. - № 6. - Одеса: «Астропринт», 2007. - С.282-288.

4. Вайшенберг 3. Новинна журналістика / 3. Вайшенберг; за заг. ред. В. Ф. Іванова. К.: Академія Української преси, 2004. - 262 с.

5. Бодрійяр Ж. Симулякри і симуляція / Ж. Бодрійяр; Переклад В. Ховхун. - К.: Вид-во Соломії Павличко «Основи», 2004. - 230 с.

6. Лотман Ю. М. Семеосфера: культура и взрыв: Ст. Исслед. Заметки / Ю. М. Лотман. - СПб.: Искусство, 2004. - 703 с.

7. Яцемірська М. Культура фахової мови журналіста: навч. посібник / М. Яцемірська. Львів: ПАІС, 2004. - 368 с.

8. Щукина Л. С. Проблема фактоидов в современной телевизионной рекламе / Л. С. Щукина // Проблемы массовой коммуникации на рубеже тысячелетий: - Воронеж, 2003. C.146. 